\title{
Fragmentation of Research Papers: Some Commentaries
}

\author{
Chee Kong Yap* \\ Department of Biology, Faculty of Science, Malaysia
}

*Corresponding author: Chee Kong Yap, Department of Biology, Faculty of Science,

Received Date: March 05, 2019

University of Putra Malaysia, Email: yapckong@hotmail.com

Published Date: March 18, 2019

\section{Commentary}

I would like to humbly comment on the very attention-grabbing paper published by [1] on 'Changing trends in authorship patterns in the JPS: Publish or perish', in Journal of Pediatric Surgery (2013;48:412-417). In my opinion, the good paper should be read by all academicians worldwide since it is not only on pediatric area but also very much has a positive connotation and connection in other areas or disciplines of study as long as a good scientific paper is concerned. Briefly, the paper has reasonably divided the explanations for the authorship pattern changes (or number of authors in published papers from three periods of study namely 1981-1986; 1991-1996; 2006-2010), into justified (ethical, acceptable) and unjustified (unethical, unacceptable) categories, according to the International Ethical Guidelines. In this paper, I would like to address my humble opinions on subject 'Fragmentation' as pointed out by [1], in order to add more deliberations and discussions.

Firstly, according to [1], Fragmentation was one of the reasons for 'Unacceptable (unethical) increase of number of authors per article'. However, it is not evidently shown that 'A positive relationship between unethical increase of number of authors per article, and paper fragmentation', does occur and thus debatable. In contrast, a negative relationship of the two could most likely be resulted because the first paper usually has a high number of authors per article while the subsequent papers by the similar main author has a fewer number of authorships.

Secondly, under 'Fragmentation', [1] pointed out that 'By dividing papers, one paper may appear as multiple separate publications (MSPs).', thus considered unethical. To a certain degree, I may agree that we should tell the whole story in a research paper but what if 'A TV serial killer story consists of 10 episodes or 10 DVDs with $4.7 \mathrm{~GB}$ per CD.' Assumingly, this may involve substantial research fundings, supporting staffs, research students/trainees, long duration of study (3-5 years) and collaborations.

Here, I would like to exemplify the above issue by metal analysis study. It is not difficult to conduct a metal analysis, but hard to obtain the correct data [2]. Simply enough the prepared samples can be sent to instrumental technicians for metal analysis without a good understanding on the know-how of the procedural analytical techniques of the instrument. Then, the metal data on biological samples should be checked and verified after a series of quality control (QC) and quality assurance (QA) activities being performed. Later, each data can only appear to be reliable and valid after a tedious and painstaking screenings on the data before these data are ready to be interpreted in research papers. It is common that some data appear to be invalid and fail to pass the QC and QA which eventually be discarded or whole metal analysis be redone. Therefore, it is justifiable and acceptable that some research projects are published in MSPs like those by [3-7] for the $\mathrm{Pb}, \mathrm{Cd}, \mathrm{Zn}$, $\mathrm{Ni}$ and $\mathrm{Cu}$, respectively.

The above on metal analysis is just one of the important sections of the whole research. There are others challenges and difficulties that had been encountered and solved during the course of whole research study before reaching successful project completion. Since a research is not completed until the findings are published in peer-reviewed journals [8], should these data be published only in a single paper? Perhaps, the researcher should not publish their whole set of data in a single paper or book chapter but in a single book instead. The reason why is quite clear now. Hence, the choice of the main researcher or author to MSPs is acceptable to some degrees. In some cases, when we read published papers which sometimes appear to be MSPs and we may speculate that the main author is trying to 'dividing/fragmenting papers. Perhaps, the readers would think as MSPs if those MSPs are actually coming 
from a single sampling and a group of samples or even from a single set of data. The same data set could be interpreted from four common different understandings of disciplines such as from biology, physics, mathematics and chemistry and even combination of two, of three, or of the four disciplines, points of view, as long as the origin of the data is truly acknowledged. Therefore, it should not be judged as unacceptable or unethical. On the other side of a coin, the acceptable practice is different from those who purposely multiply their publications by separating a small data set into MSPs, in which it is illogical supported by other misconduct in science such as plagiarism [see a notorious example by a paper by Karthikeyan et al. (2007) [9], which had clearly plagiarized the good paper by Zakaria et al. (2005) [10], and double publications which could be due to submission of a single similar title paper to more than one journals for consideration for publication. This is clearly against ethical publication value and the Journal Instructions that clearly mention that once a paper is under consideration of publication in a journal, then the same paper should not be submitted to another journal for consideration. I think it should be understood that why some authors tend to 'dividing papers', that should not be accused of salami slicing of work (SSW) or unethical. It could be explained by the following two reasons.

\section{Limitation of a Paper Length in Most Journals}

Most journals limit the number of total written words and total pages of the paper (e.g. maximum of eight pages in Bulletin of Environmental Contamination and Toxicology) to be accepted in their journals. If all the data of the whole project are to be submitted for the journal, then data or Results section only has already exceeded the limited pages without sections like Introduction, Materials and Methods and Discussion of a paper. It is also unlikely that any issue of a journal possesses a lengthy paper ( $>30$ papers) except for a special issue.

Sometimes, Novelty Point(s) of the Whole Research Project Could only be Clearly Seen if a Particular Point of Discussion with Selected Data are Conducted

Even 'selection of a few points', each point could be of high novelty that should merit publication. Sometimes, it is too confusing to present all the data into one single paper. It is more focused in interpretation and discussion on a particular point of finding if some part of the data set is separated and to be published in a separate paper. As long as the selection of data set is based on scientific grounds. For example, some ecotoxicologists with good chemistry background would like to understand a single metal behavior rather than trace metals as a whole (see Nriagu, Cabrera et al. [11-12]. Therefore, they incline to publish a paper only based on single or limited metals in separate publication. On the contrary, some ecotoxicologists with good mathematical understandings and deep interest, they tend to see multiple trace metals behaviors in development of mathematical modeling for forecast study. Rarely, we see any mathematical modeling based on a very limited data set.
Usually, the more data the better in constructing such a modeling purpose. Therefore, they prefer to publish all data set in a single publication.

Thirdly, Pintér (2013) [1] also pointed out that 'Reviewers should ensure material submitted for publication is not just a selection of a few points.' However, I reason that if the reviewers' comments are in support of the paper to be published in a peerreviewed journal, then the SSW should not be raised up. Reviewers' comments should be respected since they are the experts in the papers reviewed. We should not also totally underestimate the professional review done by expert referee although symptom of 'I am your good friend, so I approve your paper to be accepted without scientific merits basis', could not sometimes be ruled out. However, it is still arguable that the final decision by the journal Chief Editor is based on more than one reviewer's comments. If the reviewers remark that the paper is suitable for publication (even though the reviewers know the main author had published similar type of publications but with a different set of data), then the comment should be taken into consideration for the final verdict of the paper by the journal Chief Editor.

Finally, I think the right to separate the data into MSPs should lay under the responsibility of the author(s). Sometimes, some researchers prefer to publish in several publications with low impact factors (IF) or non-ISI (Institute for Scientific Information) journals, just to fulfill their annual key performance index (eg: two papers per lecturer per year). Publishing in a high IF journal would likely take a lot of time during the grounding of a paper. Again, to a certain degree, separation into different papers could cause the paper low in novelty and therefore, they are not acceptable in high impact factor journals. However, if they combine all the data set, the findings could be of high novelty enough to be accepted in any high IF journals. Therefore, the author(s) should face such consequences of their papers only be published in low ranking journals and later receive low number of citations. They should be responsible for their decisions. Then, the ethical issue on the MSPs should not be raised up as long as the misconduct in science does not present.

In conclusion, although 'fragmentation' or 'dividing papers' could be conceivably viewed as unethical in publications under certain circumstances, the understandings on the nature of the study and emergence of new science based on all the points discussed above, the practice be rather acceptable and exonerated fairly. Perhaps, the term 'fragmentation' should be viewed in a broader sense more willingly than a strictly fragmented one. Also, perhaps, the term 'dividing papers' should be revised as 'dividing papers on the ground of scientific merits', should look more apt and ethical enough.

\section{Acknowledgement}

None.

\section{Conflict of Interest}

No conflict of interest. 


\section{References}

1. Pintér A (2013) Changing trends in authorship patterns in the JPS: Publish or perish. J Pediatr Surg 48(2): 412-417.

2. Jorhem L Heavy metals in D Mello JPF (2003) Food safety: contaminants and toxins. Trowbridge: CABI Publishing Cromwell Press. 199-216.

3. Yap CK, Noorhaidah A, Tan SG (2011) Zn concentrations in the different soft tissues of Telescopium telescopium and their relationships with $\mathrm{Zn}$ speciation by sequential extraction in surface sediments: A statistical multiple linear stepwise regression analysis. In: Andrea M Bianchi, Jamie N Fields (Edts.), Gastropods: Diversity, Habitat and Genetics. Nova Science Publishers, New York, USA. 127-148.

4. Yap CK, Noorhaidah A (2011) Gill and digestive caecum of Telescopium telescopium are biomonitors of $\mathrm{Pb}$ bioavailability and contamination by $\mathrm{Pb}$ in the tropical intertidal area. Sains Malay 40(10):1075-1085.

5. Yap CK, Noorhaidah A (2011) Assessment of bioavailability and contamination by $\mathrm{Cd}$ in the tropical intertidal area, using different soft tissues of Telescopium telescopium: Statistical multivariate analyses. J Sustain Sci Manage 6(2):193-205.

6. Yap CK, Noorhaidah A, Tan SG (2012) Digestive caecum and tissue redistribution in gill of Telescopium telescopium as indicators of $\mathrm{Ni}$ bioavailabilities and contamination in the tropical intertidal area. Wat Air Soil Pollut 223:2891-2905.
7. Yap CK, Noorhaidah A, Tan SG (2013) Relationships of copper concentrations between the different soft tissues of Telescopium telescopium and the surface sediments collected from tropical intertidal areas. Int J Chem 5(1):8-19.

8. Rosenfeldt FL, Dowling JT, Salvatore Pepe, Meryl J Fullerton (2000) How to write a paper for publication. Heart Lung Cir 9(2): 82-87.

9. Karthikeyan M, Bhaskaran R, Radhika K et al. (2007) Random amplified polymorphic DNA analysis of genetic variability among isolates of Ganoderma species. Journal of Plant Diseases and Protection 114(5):205-212.

10. Zakaria L, Kulaveraasingham H, Tan SG, Faridah Abdullah, Ho Yin Wan (2005) Random amplified polymorphic DNA (RAPD) and random amplified microsatellite (RAMS) of Ganoderma from infected oil palm and coconut stumps in Malaysia. Asia Pac J Mol Biol Biotech 13(1):23-34

11. Nriagu JO (1978) Properties and the biogeochemical cycle of lead. In: Nriagu JO (Ed.), The biogeochemistry of lead in the environment, Part A. Elsevier/North-Holland Biomedical Press, Amsterdam, Europe. 1-14.

12. C Cabrera, E Ortega, C Gallego, MC Lopez, ML Lorenzo et al. (1994) Cadmium concentrations in farmlands in Southern Spain: possible sources of contamination. Sci Tot Environ 153(3): 261-265. 